University of Arkansas, Fayetteville

ScholarWorks@UARK

$11-10-2017$

\title{
Does Private Islamic Schooling Promote Terrorism? An Analysis of the Educational Background of Successful American Homegrown Terrorists
}

\author{
M. Danish Shakeel \\ University of Arkansas, Fayetteville \\ Patrick Wolf \\ University of Arkansas, Fayetteville
}

Follow this and additional works at: https://scholarworks.uark.edu/edrepub

Part of the Educational Assessment, Evaluation, and Research Commons, Educational Leadership Commons, and the Other Educational Administration and Supervision Commons

\section{Citation}

Shakeel, M. D., \& Wolf, P. (2017). Does Private Islamic Schooling Promote Terrorism? An Analysis of the Educational Background of Successful American Homegrown Terrorists. Education Reform Faculty and Graduate Students Publications. Retrieved from https://scholarworks.uark.edu/edrepub/56

This Article is brought to you for free and open access by the Education Reform at ScholarWorks@UARK. It has been accepted for inclusion in Education Reform Faculty and Graduate Students Publications by an authorized administrator of ScholarWorks@UARK. For more information, please contact scholar@uark.edu. 


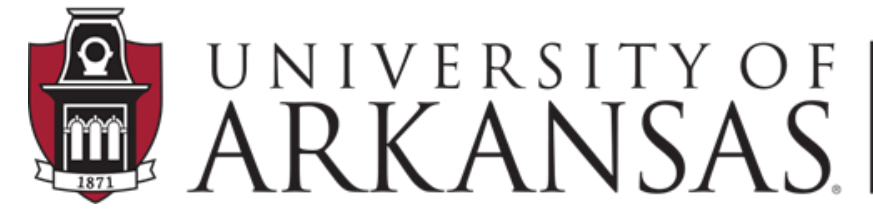

College of Education \& Health Professions Education Reform

\author{
WORKING PAPER SERIES
}

\title{
Does Private Islamic Schooling Promote Terrorism? An Analysis of the Educational Background of Successful American Homegrown Terrorists
}

\author{
M. Danish Shakeel \\ Patrick J. Wolf
}

October 16, 2017

EDRE Working Paper 2017-20

The University of Arkansas, Department of Education Reform (EDRE) working paper series is intended to widely disseminate and make easily accessible the results of EDRE faculty and students' latest findings. The Working Papers in this series have not undergone peer review or been edited by the University of Arkansas. The working papers are widely available, to encourage discussion and input from the research community before publication in a formal, peer reviewed journal. Unless otherwise indicated, working papers can be cited without permission of the author so long as the source is clearly referred to as an EDRE working paper. 


\title{
Does Private Islamic Schooling Promote Terrorism? An Analysis of the Educational Background of Successful American Homegrown Terrorists
}

\author{
M. Danish Shakeel \\ mdshakee@uark.edu \\ Department of Education Reform \\ University of Arkansas \\ 201 Graduate Education Building \\ Fayetteville, AR 72701 \\ Phone: (479) 575-3172 \\ Fax: (479) 575-3196 \\ Patrick J. Wolf \\ pwolf@uark.edu \\ Department of Education Reform \\ University of Arkansas \\ 201 Graduate Education Building \\ Fayetteville, AR 72701 \\ Phone: (479) 575-2084 \\ Fax: (479) 575-3196
}

\begin{abstract}
:
Some commentators argue that private religious schools are less likely to inculcate the attributes of good citizenship than traditional public schools (Gutmann, 1999), specifically proposing that private Islamic schools are relatively more likely to produce individuals sympathetic to terrorism (Stotsky, 2011). This study offers a preliminary examination of the question by studying the educational backgrounds of Western educated terrorists. While data are limited, in accord with prior work (Bergen \& Pandey, 2005) findings indicate the vast majority of both Islamic and reactionary terrorists attended traditional public schools and had no religious education; hence findings suggest that early religious training and identification may actually encourage prosocial behavior.
\end{abstract}

Keywords: terrorism, public schools, private schools, school choice, Islam, madrasa, Muslim, jihadist, right wing, homegrown terrorists. 
With regards to three dimensions (reflection, skills, and attitudes) pupils at Islamic schools score considerably higher than pupils at comparable schools, and still higher than pupils at the average school. Only with regard to knowledge competence do pupils at Islamic schools score nearly the same as pupils at comparable schools, but significantly lower than pupils at the average school. These findings directly challenge the assumption that pupils at Islamic schools are less likely to cultivate the relevant civic virtues for Dutch society at large. Jaap Dronkers, 2016, pp. 14-15.

The late, eminent sociologist Jaap Dronkers possessed an impressive set of academic skills and virtues (Wolf, 2016). He delved, courageously, into controversial topics with an open mind and an incisive set of analytic tools. The fruits of his scholarship included his pioneering study of the civic skills and attitudes of students in private Islamic schools in The Netherlands, published just before his untimely death. Contrary to popular belief, Dronkers concluded, Dutch Islamic schools appeared to be doing a good job of preparing students to be law-abiding, democratic citizens (Dronkers, 2016). In this article, we examine whether Dronkers' findings regarding Dutch private schools and civic values appear to apply to the U.S. context and the most un-civic of behaviors: terrorism.

Despite the considerable media and law enforcement attention it draws, terrorism in the West is rare, and typically conducted by individuals or small groups, limiting empirical analyses (Biglan, 2015; Berman et al., 2015). ${ }^{1}$ The extant empirical work on terrorism questions conventional wisdom about the phenomena. Pape's profiles of modern suicide bombers as of 2003 indicate that religion was a primary motivation in only 5\% of cases. Rather "suicide

\footnotetext{
${ }^{1}$ We thank Charles Leslie Glenn, Jr., of Boston University and Robert Maranto and Dirk C. van Raemdonck of the University of Arkansas for comments on earlier drafts. All remaining flaws are ours. Corresponding author is M. Danish Shakeel, mdshakee@uark.edu.
} 
terrorism is mainly a response to foreign occupation rather than the product of Islamic fundamentalism" (Pape, 2005, p. 237). Terrorism has since evolved, with an incremental rise of Western born and raised individuals joining foreign battlefields or attempting to commit acts of terror in their homelands. Case studies employ political environment and socioeconomic variables to explain these individual decisions to participate in acts of terror. Possible causes of contemporary terrorism include religious indoctrination (Hindery, 2003; Schbley, 2003) and social and psychological alienation (Lyons-Padilla et al., 2015; Stern, 2016). While studies try to examine potential causal variables that may explain radicalization, the individual, social and political variables involved are endogenous to other key variables such as religion and culture.

Lyons-Padilla et al. (2015) finds that cultural homelessness and attendant alienation among American Muslim immigrants is associated with increased support for fundamentalist groups and extremist causes. Bhatt and Silber (2007) proposes four phases of radicalization for the Western jihadist terrorist: 1) pre-radicalization, 2) self-identification, 3) indoctrination and 4) jihadization. Religious education may play a role in these phases of radicalization. Often, private Islamic schools are accused of producing individuals who commit acts of terror (Stern, 2000), but Bergen \& Pandey (2005) point out that Western jihadists largely do not attend Islamic schools. They note, "while madrassas may breed fundamentalists who have learned to recite the Koran in Arabic by rote, such schools do not teach the technical or linguistic skills necessary to be an effective terrorist." (Bergen \& Pandey, 2005, p. A23) Out of the 75 profiles of terrorists who attacked Western targets, only nine had attended madrasas. Their study did not parse out the data between homegrown vs. foreign terrorists and by schooling type, probably due to small sample size. 
Few Western terrorists majored in religion during their religious studies (Gambetta, \& Hertog, 2016). Classic work by Hoffer (1951) shows how radicals differ from the rest of society. Since many commentators see religious schooling as a form of indoctrination (Dawkins, 2006; Harris, 2011; Americans United, 2011), it is important to examine possible relationships between religious schooling and terrorism.

The purpose of this study is to offer a preliminary exploration of whether religious schooling in general and Islamic schooling in particular is associated with participation in terrorism. American government and international aid agencies have funded programs to strengthen the educational effectiveness of public schools, but not religious schools, in majorityMuslim nations since September 11, 2001. Efforts to reduce terrorism by replacing religious schools with public schools may be counter-productive. Experimental and quasi-experimental studies in the United States and Europe indicate that private school choice interventions tend to produce positive outcomes for civic values (Wolf, 2007; Forster, 2016), or at least do no harm in that area (Dronkers, 2004; Carlson, Chingos \& Campbell, 2017). Thus, carefully designed school choice interventions may decrease terrorism by reducing the numbers of young recruits who attempt to commit violent acts.

To explore the possibility that religious schooling might not be causing, and in fact might be hindering, terrorism, this article analyzes the schooling of native born Americans who succeeded in committing an act of terror inside the United States. We first outline the role of quality instruction grounded in an authentic understanding of Islamic tradition, culture, and values in discouraging terrorism, as well as the role of independent religious schools in delivering such instruction. The paper argues that decentralized and market based schooling better facilitates tolerance in comparison to centralized and government controlled schooling 
(Berner, 2017; Coulson, 1999; Friedman, 2002; Glenn, De Groof, \& Candal, 2012). We suggest that religious extremism and recently Islamic extremism is a byproduct of the lack of access to quality religious education, government hindrance of school choice and the lack of pluralism in public schooling and not necessarily caused by religious schooling. We use the coding of historical cases and summary statistics to support our claims. This preliminary analysis suggests that school choice interventions may, over the long term, reduce the incidence of terrorism in Western societies.

\section{Contextual history and theory of Islamic schooling and organization}

Five framing considerations are vital to our exploratory study. First, Islam has a long and storied educational tradition that mainly has been privately operated and decentralized. Second, the major branches of Islam, Sunni and Shia, are distinct in ways that inform our consideration of private school choice and terrorism. Third, traditionalism and fundamentalism is a second distinction within Islam that is largely independent of the Sunni-Shia divide. Fourth, a lack of exposure to high-quality religious instruction appears to be contributing to the modern terrorist activity of some Muslims. Fifth, high-quality Islamic religious instruction in the West is likely to be fostered by a system of private Islamic schools financially supported and partially overseen by government.

\section{Islamic schooling tradition}

Up to the eleventh century, Islamic schooling was primarily self-funded and philanthropic. Schooling in mosques and in the madrasas took place free of government intervention. Egger (2004, p. 220) notes "[t]he madrasa never displaced the mosque as an educational institution. In fact, Muslims were never precise in distinguishing between the two, because education and worship took place in both." This period is often remembered as the 
golden age of Islam due to its high scholarly accomplishment and education attainment.

Increased state intervention in schooling starting in the eleventh century occurred contemporaneously with a decline in Islamic scholarship and reduced tolerance of minorities, perhaps reflecting regime goals superseding religious goals. Decentralization and a market orientation were the key attributes of Islamic schooling up to that time (Coulson, 1999; Durrant, 1950, p. 94, 304).

\section{The Sunni-Shia distinction}

Religious tradition is often complicated. Much of Sunni Islam is decentralized whereas Shia Islam is essentially centralized. This distinction has important implications. The violent extremists of Sunni Islam become self-empowered and interpret Islam in ways that justify their values and actions (Gambetta, \& Hertog, 2016). Sunni extremists practice violence horizontally while Shia extremists do so vertically, meaning that the former harm fellow religious comrades and declare them as apostates while the latter target 'perceived opponents.' By every count AlQaeda, Taliban, ISIS and other Sunni terrorist organizations have killed far more Sunni Muslims than other groups have done. On the other hand, Shia Militias seldom attack their co-religionists, largely because Shia central authorities (Ayatollahs) must authorize such violent acts.

\section{Islamic traditionalism versus fundamentalism}

The divide between Islamic traditionalism and fundamentalism is central to the schooling and terrorism story. Traditionalism involves following the four jurisprudential schools of thought in Sunni Islam of Hanafi, Shafi'i, Hanbali and Maliki. Fundamentalism rejects these established theological practices and often goes against the theological consensus of the traditionalist interpretations, called the ijma. Traditionalists are less likely than fundamentalists to get involved 
in terrorism as traditionalists are influenced by historic institutions, scholarly consensus and a variation in interpretation of religious texts, all of which possess market attributes.

Traditionalists view family and civic values as highly salient, while these commitments tend to be weaker for fundamentalists. Literal interpretation of the text of The Quran is central to the fundamentalist doctrines of Salafism and Wahhabism (Hill, Knitter, \& Madges, 1997). Fundamentalism lacks mass appeal, but in societies where socio-economic and political vacuums exist, fundamentalism has gained legitimacy. Almost all major Sunni terrorist organizations identify their ideology as fundamentalist (Salafism or Wahhabism). In the theological sense, Sunni fundamentalism confronts the theological consensus of traditionalist Muslim scholars and jurists. The majority of Islamic fundamentalists do not practice violence yet the correlation between fundamentalism and violence is strong. We now focus on the possibility that quality Islamic instruction could moderate the trail to terror for Sunni fundamentalists that form the majority.

Quality instruction grounded in an authentic understanding of Islamic tradition, culture, and values

Growing numbers of new converts to Islam have suddenly joined jihad. Ten to 25 percent of terrorists are Western converts to Islam, including approximately 30 percent of American jihadists, a remarkably high percentage given their very small numbers (Roy, 2008; New America, 2017). While most life-long Muslims have received a substantial amount of religious instruction in their mosques and schools, converts to Islam lack depth to their Islamic training due to a general lack of exposure to quality Islamic instruction.

This article defines quality Islamic instruction as grounded in an authentic understanding of Islamic tradition, culture, and values. High quality instruction, regardless of topic, promotes cognitive outcomes like educational achievement and attainment and also non-cognitive 
outcomes like grit and perseverance. For example, Dutch Islamic schools outperform comparison schools in improving student non-cognitive skills on three dimensions: reflections, skills, and civic attitudes and have a positive effect on student cognitive outcomes after controlling for student socio-economic background (Dronkers, 2016).

A lack of quality religious instruction grounded in an authentic understanding of Islamic tradition, culture, and values appears to contribute to terrorist activity. Most Western terror recruiters and the individuals who commit terror are less likely to know classical Arabic or be trained in traditional Islamic sciences ${ }^{2}$ and thus lack the authority to issue a fatwa $^{3}$ (Kareem, 2014; Oakford, 2014). In lieu of quality Islamic instruction, the typical Islamic consumer may not be able to distinguish between the opportunity cost of choosing the religious signal from a traditionalist who opposes terrorism over that of a fundamentalist who condones or encourages it.

Many Muslim youth in the West lack a religious identity, as they neither attend mosque nor vigorously nurture a strong religious identity (Haddad \& Lummis, 1987; Smith, 2000). Qualitative work in Islamic schools shows that children draw upon Islamic education for their identity and to give their life meaning (Driessen, \& Valkenberg, 2000; Hussain, \& Read, 2015; Mohme, 2017; Smith, 2000; Zine, 2006). Lack of access to quality \& overtly religious schooling is thus not a boon but a bane for promoting civic values (Berner, 2017). The traditional public schools are often large, bureaucratic, and lack religious and other values. Hence, they leave

\footnotetext{
${ }^{2}$ Traditional Islamic sciences include Islamic jurisprudence and its methodology primarily based on the Quran and the traditions of the prophet of Islam. Islamic sciences differ from western sciences as the former are laid around revealed Islamic texts and spirituality. Worship forms the core of the former while for the latter acquiring material knowledge is the main motivation.

${ }^{3}$ Literal meaning is Islamic opinion (it takes the form of a verdict when issued by a jurist). In Western democracies, a fatwa is often a non-binding Islamic verdict issued by an influential religious authority.
} 
young people hungry for meaning (Berner, 2017; Chubb, \& Moe, 1990; Powell, Farrar, \& Cohen, 1985).

Western Islam seeks to be in accord with modernity. Almost all Western mosques welcome Muslims of both genders. The challenge for Islam, however, is that new converts to the faith and the current generation of Muslims coming of age in the West often lack access to quality instruction to communicate the theological depth, diversity, traditions, and values of Islam. The social and purposive needs of Muslims, especially if they are young or converts to the religion, may be better addressed through private schools of choice, as market oriented organizations are better at dispensing incentives to individuals to prompt them to contribute activity to collective enterprises (Clark and Wilson, 1961). Under school choice systems, consumers are able to maximize their religious, spiritual and cultural utility by their choice of a school for their child. Such programs operate under the purview of the legal and democratic process (Wolf \& Macedo, 2004; Glenn, De Groof, \& Candal, 2012; Mohme, 2017).

\section{Role of independent religious schools}

Limited local access to quality religious instruction creates a bad market for the potential Islamic consumer. The problem concerning religious extremism and Islam, we contend, can be thought of as an example of market failure. The market for Islamic religious instruction in most parts of the world arguably is suffering from a lack of four key market components: (1) quality options, (2) variation in theological instruction, (3) operational autonomy from the state, and (4) competition among religious institutions based on observable outcomes. Increases in the delivery of education specifically through government schooling reduces the variance in Islamic theological instruction by reducing the size of the market for religious schools. State intervention in religious institutions also gives rise to special interest groups, which, if fundamentalist, 
become a source for the government to stay in power. Consequently, fundamentalism gains influence in the absence of local quality options, as we have seen recently in Iran, Saudi Arabia and Pakistan.

Religious education is handled, broadly, in three different ways across countries (Wolf \& Macedo, 2004; Glenn, De Groof \& Candal, 2012). In most nation-states, religious schools operate entirely in the private sector, with no subsidies and little involvement from government. Some countries, from the Middle East to Great Britain, provide faith based religious instruction in government-run public schools. For political reasons such as regime maintenance, these governments influence the instruction in religious schools. Finally, many Western countries permit private religious schools to receive government subsidies to support the education of students that choose to attend such schools (Dronkers \& Robert, 2008). Even though the government regulation of religious schools under private school choice systems ranges from minimal to only moderate at most (Glenn, De Groof, \& Candal, 2012), a substantial amount of research shows that private school choice contributes to civic values and tolerance, and no evidence indicates that civic attitudes and social cohesion degrades due to school choice (Greene, 1998; Dronkers, 2004; Wolf, 2008; Shafiq \& Myers, 2014; Carlson, Chingos, \&Campbell, 2017).

Religious schools might be more apt to promote civic values as they cater to the spiritual development of the soul and encourage stronger family ties. Wolf (2008, p. 487) says "[t]his seems to be the case particularly among ethnic minorities (such as Latinos) in places with great ethnic diversity (such as New York City and Texas), and when Catholic schools are the schools of choice." The overlap of education and religion is not new to the Western democracies and the local churches played a role in the original American public schools. Ironically, while America 
denies the role of religion in its public schools, many European democracies have embraced school choice that includes state-funded religious schools (Berner, 2017; Maranto \& van Raemdonck, 2015).

As private schools, we contend that religious schools are best accountable to consumers in the form of parents and not to the government. Chubb and Moe (1990) develop the likely superiority of consumer rather than state driven schooling. They argue that institutional reform is the key to better schools and an indirect control of the schools through markets and parental choice is the best hope for educational effectiveness.

Numerous studies done on private schools have established that religious schooling contributes to civic values and practices much more strongly than public schooling (DeAngelis \& Wolf, 2016; Bettinger \& Slonim, 2006; Mills \& Wolf, 2016). Dronkers (2016) shows that Dutch Islamic schools not only have a positive value added for student achievement after controlling for socio-economic background, but also the schools do well on non-cognitive measures. Merry and Driessen (2016) report that in 2002, the Dutch Education Inspectorate concluded that $90 \%$ of the Islamic schools were aiding the process of integration of Muslims in Dutch society. Abernathy (2005) notes that increased competition due to school choice affected the voting behavior for the state of New Jersey. Basford and Traeger (2014) have shown Somali students adapted to civic values and expressed a greater acceptance of American society in the ethnocentric charter schools in Minneapolis, consistent with similar findings for Somalis in the private school choice environment of Sweden (Mohme, 2017). Catholic schooling in the U.S. has contributed to successful integration in society (Bryk, Lee, \& Holland, 1993). Catholic schools enroll growing number of non-Catholic and minority students (McDonald, 2000) and produce equal or better civic outcomes than traditional public schools (Wolf, 2007; Berner, 2017). The 
relatively new Islamic schools in the U.S. are likely to contribute towards the common good in a similar fashion to the relatively older Catholic schools. Thus, a deep grounding in one's faith and religious community through Islamic schooling can in fact facilitate successful assimilation within a largely secular society. We argue this holds for Islamic schools in the cultural West.

In contrast, state control or state influence in religious schools has a history of promoting intolerance when compared to decentralized and privately administered religious schools. There are far fewer fighters in the Syrian and Iraqi battlefields from India, which is home to the thirdlargest population of Muslims, ${ }^{4}$ than from other Muslim and Western countries. Concerning the ongoing wars in Iraq and Syria, calculations ${ }^{5}$ for number of foreign fighters per million people by the International Centre for the Study of Radicalization and Political Violence do not list India. This is not to say that few Indian Muslims have not gone overseas to join the terrorist organizations, but their representation is least after taking the Indian Muslim population's size and India's history of religious conflicts in account. India's religious schools are largely free of government control and the Islamic religious institutions (madrasas ${ }^{6}$ ) in India have strongly protested any government attempt to bring the religious institutions under its control.

Conditions differ where the state regulates religious schools to promote particular religious schooling for regime support. There could be objections to this hypothesis that the geopolitics of the countries are different, however, none other than Al-Qaeda expressed frustration with this by releasing a video entitled 'Why is there no storm in your river?' (Ahmad, 2013). AlQaeda's frustration with Indian Muslims has continued to grow till today. ${ }^{7}$ The Syrian and Iraqi

\footnotetext{
${ }^{4}$ Hackett (2015) says that by 2050, Indian will have world's largest population of Muslims.

${ }^{5}$ http://www.rferl.org/a/foreign-fighters-syria-iraq-is-isis-isil-infographic/26584940.html

${ }^{6}$ Islamic schools, mostly prevalent in parts of Asia and Africa.

${ }^{7} \mathrm{http}$ ://timesofindia.indiatimes.com/india/zakir-musa-slams-indian-muslims-for-not-joining-jihad-calls-themworlds-most-shameless/articleshow/59010014.cms
} 
battlefield has more fighters from Western nations both in numbers and in proportion to their Muslim population than from many Muslim majority nations. Weaver (2015) says "More British Muslims have joined Islamist militant groups than serve in the country's armed forces." Sociology should address why Indian Muslims, who arguably have genuine grievances, join foreign battlefields in far lower proportions than Pakistani, Saudi, and Western raised individuals. A potential explanation is the existence of state-independent madrasas in India, which provide the Muslims with stakes in the system and thus reduce radicalization and terrorism.

In summary, observers may be incorrect in ascribing the trail to terror to Islamic religious schools. The assumption that public schools promote tolerance and private religious schools promote intolerance should be empirically tested. An important arena in which to test this claim is regarding the most intolerant of acts: terrorism in the cultural West. Islamic schools operating independently in choice-based educational markets need to please parents, who, after all, do not want their children to become terrorists. State support for authentic Islamic religious schools in the West could provide the instruction for young Muslims truer to the Muslim faith and less critical of the West because it would be transparent and subject to public scrutiny. O'Neill (2010, p. 68) notes that a majority of Islamic schools in the U.S. are governed independently of local mosques. Independent religious schools, supported by the state, could be a highly effective antiterrorism vehicle in the cultural West. We think that the evidence from terrorist activities to date provide empirical support for our claim.

\section{Data}

This section describes the data sources for testing if religious and specifically Islamic schooling is associated with successful cases of homegrown terror or not. Before beginning the 
project, we contacted major experts in the area to get their views on the question of private schooling and western terrorists. The views by Robert Pape at the University of Chicago, Thomas Hegghammer at the Norwegian Defence Research Establishment, Diego Gambetta at European University Institute, Joshua Freilich at The City University of New York and Brent Smith at the University of Arkansas were constructive. The New America Foundation provided the complete list of fatal jihadist and right wing attacks since 9/11. Databases like The National Consortium for the Study of Terrorism and Responses to Terrorism (START) at the University of Maryland were also searched to see if they collected information on the educational background of terrorists. Freilich et al. (2014) provided useful data which was crosschecked with the other sources. Mueller (2013) included individual case studies which helped us trace the history of western terrorists. Internet searches were used to fill some data gaps. We combined all of this information into a single database of the educational and backgrounds of all western terrorists since $9 / 11$. To the best of our knowledge, our database is the first to codify information on all levels and types of schooling of western terrorists. We then used the database to test the claim that private religious schooling promotes terrorist activity.

\section{Research Design}

The study is based on collecting the high school profile of individuals raised in the West who successfully committed acts of terror on the western soil. The article does not delve into questions of foreign and domestic politics or religion and ideology since they have been studied elsewhere, as described in the framing sections above. This study focuses on the single vital question of the association between private education and extreme intolerance in the form of terrorism. 
Although our analysis is confined to acts of terror in the U.S., we discuss some European terror events to explore the external validity of our findings. We focus our research on the U.S. because:

1) It does not share a border with countries that directly suffer terror or insurgency, so terrorist infiltration is of little concern (Laqueur, 2016).

2) It does not have a territorial dispute that is tied to acts of terror.

3) It is not known to have inflicted state sponsored violence on citizens in the post-Soviet era. ${ }^{8}$

4) It is economically prosperous and defends many individual liberties, so individuals born and raised in the U.S. have few obvious motivations to commit acts of terrorism.

Indeed, Francis Fukuyama (1992), in The End of History and the Last Man, claimed there existed a consensus that the West had discovered the formula for societal success. All countries, according to Fukuyama, would soon evolve toward the model of capitalist democracy common in North American, Europe, the much of Asia. Until quite recently, with the notable exception of the IRA and Basque separatists in Spain, domestic terrorism was almost non-existent in the west.

To the best of our knowledge, no prior research has examined systematically the educational background of Western born terrorists. As a preliminary analysis, we focus only on the high school level of education, recording attendance at public or private schools. Data for schooling of all the terrorists at all levels from K-12 is not available. A lack of control variables measuring non-schooling factors that could influence terrorist activity means that our analysis is merely exploratory and not causal. Although even a single act of terror is a regrettable horror,

\footnotetext{
${ }^{8}$ We have thus excluded South Asia, China, Russia, Middle East, South East Asia and Northern Africa and other regions.
} 
from a statistical sense, the sample of people who have committed terrorist acts in the U.S. since 9/11 is small. Future associations between private schooling and terrorist activity might be different should additional acts take place that diverge from the pattern we describe here.

The terrorists analyzed in this paper are limited to those born and raised in the U.S., with right-wing affiliations, who actually managed to commit an act of terror. We limit our study to right-wing terrorists because Jihadist ideology is a politically conservative form of extremism (Lee, 2011). For example, Ismaaiyl Brinsley ${ }^{9}$ may have been inspired by Black Lives Matter but we exclude his case because BLM does not advocate violence and is not politically conservative. Similarly John Allen Muhammad, the "Beltway sniper", was a U.S.-born Muslim who spread terror but his purpose was to kill his ex-wife in order to gain custody of their children. The terrorism he engaged in was instrumental to making his wife's murder look like a terrorist act, so we exclude him. Naveed Afzal Haq clearly committed an act of terror but his prior actions include arrest for public exposure and other behaviors that suggest mental illness, and not rightwing ideology, motivated him to commit terror. Finally, we exclude cases such as Alton Nolen in Oklahoma where the possible terrorist was accused but never legally charged with a terror-linked crime. ${ }^{10}$ One takeaway from the data below is that there really are not very many actual successful U.S. born and raised ideologically motivated Muslim terrorists, certainly not compared to Europe. But are private Islamic schools associated with the few terrorists who have emerged from the American Muslim community over the past 16 years? That is our question here.

Consistent with the principles of Bayesian inference (Edwards, Lindman \& Savage, 1963), we first determine the percentage of Muslims in the U.S. who attend private high schools

\footnotetext{
${ }^{9}$ Information available at http://www.start.umd.edu/gtd/search/IncidentSummary.aspx?gtdid=201412200060

${ }^{10}$ Information available at http://securitydata.newamerica.net/extremists/terror-plot.html?id=1793
} 
to find an empirical basis for an increased likelihood of a U.S. Muslim committing terrorism due to attending private Islamic schools. Then we compare that likelihood of having attended a private high school, given that a person is an American Muslim, with the likelihood of them having been privately educated, given that they committed a terrorist act.

\section{Results}

We conduct separate analyses of explicitly jihadist terrorists (table 1 A) and non-jihadist right-wing terrorists (table $1 \mathrm{~B}$ ). Out of the twelve profiles of jihadist terrorists, we could collect educational data on only seven. For the thirty-three profiles of right-wing non-jihadist terrorists, we could collect educational data for only fifteen. All seven jihadist individuals are males who attended public schools. Of the fifteen right-wing non-jihadist terrorists for which we were able to obtain data, eleven attended public schools, three attended private schools, and one was homeschooled.

[table 1 A about here]

[table $1 \mathrm{~B}$ about here]

To determine if these limited associations between private schooling and terrorism suggest a connection between the two, we consult data on private school attendance in general and private Islamic school attendance in particular. In 2013-2014, 208 private Islamic schools in the U.S. enrolled 35,295 students (National Center for Education Statistics, 2017a). A total of 4,097 students were enrolled in Islamic high schools that year, representing just .03 percent of the 15.3 million secondary school students that year, as most Islamic schools in the U.S. end at grade 8 (Keyworth, 2006). O’Neill (2010, p. 5) reports that only three percent of American Muslims attend private Islamic schools. Since approximately ten percent of high school students in the U.S. attend private schools (National Center for Education Statistics, 2017b), the 
likelihood of a Muslim attending a private Islamic school is lower than the general likelihood of private school attendance. Given that a U.S. born adult is a Muslim, there is a 3 percent chance that he attended a private school. Given that a U.S. born adult is a Muslim terrorist, there is a 0 percent chance that he attended a private high school. Thus, although the actual educational histories of seven Muslim terrorists do not support the claim that private Islamic schools encourage people to commit terrorist acts, they also do not necessarily support the claim that private Islamic schools discourage people from becoming terrorists. It is possible that the main reason why no U.S. Muslim terrorists have been privately educated is because so few U.S. Muslims attend private Islamic schools.

The evidence regarding non-jihadist right-wing terrorists is similarly inconclusive. Given that a person is a U.S. born adult, there is a 10 percent chance that he attended a private high school. Given that a U.S. born adult is a right-wing terrorist, there is a 20 percent chance that he attended a private high school. Although private school attendance is associated with a higher likelihood of having committed a right-wing terrorist act, with only 15 cases to draw from, this preliminary analysis is only suggestive of such a link.

\section{Conclusion and Policy Implications}

With limited data, this analysis indicates that there is lack of empirical basis to claim that religious and specifically Islamic schooling in the United States is associated with homegrown terrorism. Among the U.S.-raised Muslims charged with committing or attempting to commit acts of terrorism in the west, all for whom we have data attended traditional public schools. There is an interesting historical analogy, in that in the 19th and early 20th Century American Catholic schools were seen as divisive to the polity. In fact, as the past 30 years of research has shown, Catholic schools seem to increase rather than decrease patriotism, civic activity, 
tolerance as well as effectiveness (Bryk, Lee \& Holland, 1993; Manno \& Graham, 2001;

Campbell, 2008). The same could be true of Muslim schools in the U.S.; however, their current small scale provides little evidence at this point to confirm that possibility.

Greater access to religious schooling may benefit the society and religious schooling may moderate the frequency of acts of terror in the West. A key recommendation for policy makers is to encourage decentralized and private school choice and evaluation of Islamic schools based on measurable outcomes. This recommendation is especially acute as Muslim nations suffer from bad governance, unpopular regimes, restless and uneducated youth (Hackett et al., 2016; Ummid news, 2015). Decentralized and private religious schooling could moderate the causal link between hate and violence in the form of terrorism. Local quality Islamic education and the higher education of Imams of mosques in U.S. universities may also promote tolerance among Muslims. A lack of quality local schooling options in the Middle East have increased the role of Saudi Salafi and Wahhabi Islam funded by petrodollars. A market oriented approach to Islamic schooling can increase adherence to the traditional approach to Islam and weaken fundamentalism. Government can aide this process through greater access to private religious schools. An alternate approach is to also provide religious instruction in existing public schools; this may increase the plurality of public education that may add to creating democratic citizens (Berner, 2017). In many cases it could be possible that the marginal terrorist can be brought back to sanity if his or her spiritual and social needs can be met through religious schooling.

School choice has the potential to serve disadvantaged minorities better than public schools (Tooley, 2009; Muralidharan \& Sundararaman, 2015; Howell \& Peterson, 2006). In religious private schools, students from other religions and cultures self-select for a better quality of education, generating social and religious diversity within such private schools (Trivitt \& 
Wolf, 2011). It is surprising to know that this doesn't only happen in affluent Catholic schools in some countries outside the U.S. but also in some of the not so affluent Islamic schools in India which Hindu students self-select into for educational needs (Al Jazeera English, 2013). This shows that the market produces more options for diversity and acceptance by choice. The schools created for the disadvantaged minorities in a free-market would be open to everyone. The decision to create a school for minorities would again be based on consumer demand and not regime goals that might be antithetical to political tolerance.

We acknowledge that some findings of terrorists having attended religious private schools goes against our hypothesis that market and plural education is better than a statist approach to education. However, as mere attendance at a public school does not make one a democratic citizen, mere attendance at a religious school does not make one a fundamentalist or terrorist. Further research is need for the few cases where terrorists attended religious schools to see if religious values were in fact translated to these individuals at the schools. Additionally, researchers need to examine if terrorists built a socio-religious identity due to their religious schooling that then led them strike at their fellow citizens with terrorism. We hypothesize they did not.

This study aims to encourage further research into the education profiles of people who commit violence and, secondly, calls for evaluation and proper design of Islamic curriculum in schools which can cater to the social and spiritual needs of Muslims. Independent researchers, child psychologists, trained religious instructors and sociologists should build upon the pioneering work of Jaap Dronkers in this field. To support such research, government agencies should produce more detailed and comprehensive databases regarding the backgrounds of people who commit terrorist acts. We drew from multiple data sources for this study and still only 
obtained the evidence that we needed from about half of the cases that could have been included in the study.

We think there is good reason to believe that providing increased access to modern Islamic schooling in the U.S. would address the spiritual and religious needs of Muslim students. Providing people with a stake in society through a system of school choice can be a way to moderate any inclination towards terrorism. We look forward to more research on this vital topic. 


\section{References}

Abernathy, S. F. (2005). School choice and the future of American democracy. University of Michigan Press.

Ahmad, T. (2013). (2013, June 27). Al-Qaeda's India dilemma. The New Indian Express. Retreived from http://www.newindianexpress.com/columns/Al-Qaedas-Indiadilemma/2013/06/27/article1654347.ece

Al Jazeera English. (2013). Madrassas in India Attract Hindu Students. Retrieved from http://www.aljazeera.com/indepth/spotlight/indiaonline/2013/11/madrassas-india-attracthindu-students-2013111814457229891.html

Americans United for the Separation of Church and State. (2011). 10 reasons why private school vouchers should be rejected. Retrieved from https://www.au.org/church-state/february2011-church-state/featured/10-reasons-why-private-school-vouchers-should-be.

Basford, L. E. \& Traeger, H. M. (2014). A Somali school in Minneapolis. In Fox, R. A., \& Buchanan, N. K. (Eds.). Proud to be different: Ethnocentric niche charter schools in America. R\&L Education.

Bergen, P. \& Pandey, S. (2005, June 14). The madrassa myth. New York Times.

Berman, E., Felter, J., Kapstein, E. B. \& Shapiro, J. (2015, March 16). How empirical studies of political violence (can) help policymakers. Washington Post. Retrieved from http://www.washingtonpost.com/blogs/monkey-cage/wp/2015/03/16/how-empiricalstudies-of-political-violence-can-help-policymakers/

Berner, A. R. (2017). Pluralism and American public education: No one way to school. Springer. 
Bettinger, E., \& Slonim, R. (2006). Using experimental economics to measure the effects of a natural educational experiment on altruism. Journal of Public Economics, 90(8), 16251648.

Bhatt, A., \& Silber, M. D. (2007). Radicalization in the west: The homegrown threat. New York: New York City Police Department.

Biglan, A. (2015, March 8). Where terrorism research goes wrong. The New York Times, p. SR12. Retrieved from http://www.nytimes.com/2015/03/08/opinion/sunday/whereterrorism-research-went-wrong.html?action=click\&pgtype=Homepage \&version=Moth$\underline{\text { Visible\&module=inside-nyt-region \& region=inside-nyt-region } \& W T . n a v=i n s i d e-n y t-}$ $\underline{\text { region } \& \text { assetType }=\text { opinion } \& \_r=1}$

Bryk, A. S., Lee, V. E., \& Holland, P. B. (1993). Catholic schools and the common good. Harvard University Press.

Campbell, D. E. (2008). Civic side of school choice: An empirical analysis of civic education in public and private schools, The. BYU L. Rev., 487.

Carlson, D., Chingos, M.M., \& Campbell, D.E. (2017). The effect of private school vouchers on political participation: Experimental evidence from New York City. Journal of Research on Educational Effectiveness, 10(3), 545-569.

Chubb, J. E., \& Moe, T. M. (1990). America's public schools: Choice is a panacea. The Brookings Review, 8(3), 4-12.

Clark, P. B., \& Wilson, J. Q. (1961). Incentive systems: A theory of organizations. Administrative science quarterly, 129-166.

Coulson, A. J. (1999). Market education: The unknown history (Vol. 21). Transaction Publishers. Dawkins, R. (2006). The god delusion. Houghton Mifflin Company. 
DeAngelis, C., \& Wolf, P. J. (2016). The school choice voucher: A 'get out of jail' card?. Available at SSRN 2743541.

Driessen, G., \& Valkenberg, P. (2000). Islamic schools in the Netherlands: compromising between identity and quality?. British Journal of Religious Education, 23(1), 15-26.

Dronkers, J. (2004). Do public and religious schools really differ? Assessing the European evidence. In Wolf, P. J., \& Macedo, S. (Eds.), Educating citizens: International perspectives on civic values and school choice (287-312). Brookings Institution Press.

Dronkers, J., \& Robert, P. (2008). Differences in scholastic achievement of public, private government-dependent, and private independent schools: A cross-national analysis. Educational Policy, 22(4), 541-577.

Dronkers, J. (2016). Islamic primary schools in The Netherlands. Journal of School Choice, $10(1), 6-21$.

Durant, W. (1950). The age of faith: A history of Medieval Civilization-Christian, Islamic, and Judaic-from Constantine to Dante: AD 325-1300. The Story of Civilization, Part Four. Simon \& Schuster.

Edwards, W., Lindman, H., \& Savage, L.J. (1963). Bayesian statistical inference for psychological research. Psychological Review, 70, 193-242.

Forster, G. (2016). A win-win solution: The empirical evidence on school choice. Indianapolis, IN: Friedman Foundation for Educational Choice.

Friedman, M. (2002). Capitalism and freedom. University of Chicago Press. Freilich, J,D., S.M. Chermak, R. Belli, J. Gruenewald, \& W. Parkin. (2014). Introducing the United States extremist crime database. Terrorism and Political Violence. 26(2): 372384. 
Fukuyama, F. (2002). The end of history and the last man. Simon and Schuster.

Gambetta, D., \& Hertog, S. (2016). Engineers of jihad: The curious connection between violent extremism and education. Princeton University Press.

Glenn, C. L., De Groof, J., \& Candal, C. S. (2012). Balancing freedom, autonomy and accountability in education. Wolf Legal Publishers (WLP).

Greene, J. P. (1998). Civic values in public and private schools. Learning from school choice, 83-106.

Gutmann, A. (1999). Democratic education. Princeton University Press.

Hackett, C. (2015). By 2050, India to have world's largest populations of Hindus and Muslims. Washington, DC: Pew Research Center. Retrieved from http://www.pewresearch.org/fact-tank/2015/04/21/by-2050-india-to-have-worlds-largestpopulations-of-hindus-and-muslims/

Hackett, C., McClendon, D., Potančoková, M., \& Stonawski, M. (2016). Religion and education around the world. Washington, DC: Pew Research Center. Retrieved from http://www.pewforum.org/2016/12/13/religion-and-education-around-the-world/

Haddad, Y. Y., \& Lummis, A. T. (1987). Islamic values in the United States: A comparative study. Oxford University Press, USA.

Harris, S. (2011). The moral landscape: How science can determine human values. Simon and Schuster.

Hill, B., Knitter, P. F., \& Madges, W. (1997). Faith, religion \& Theology: A contemporary introduction. Twenty-Third Publications.

Hindery, R. (2003). The anatomy of propaganda within religious terrorism. The Humanist, 63(2), 16. 
Hoffer, E. (1951). The true believer: Thoughts on the nature of movements. New York NY: HarperCollins.

Howell, W. G., \& Peterson, P. E. (2006). The education gap: Vouchers and urban schools. Washington, DC: Brookings Institution Press.

Hussain, S., \& Read, J. N. G. (2015). Islamic schools in the United States and England: Implications for integration and social cohesion. Social Compass, 62(4), 556-569.

Kareem, B. A. (2014). What we learn from ISIS list of "scholars." Retrieved from http://www.bilalabdulkareem.com/scholars1/

Keyworth, K. (2006). Trial by fire: Islamic schools after 9-11. Islamic Schools League of America.

Laqueur, W. (2016). A history of terrorism: Expanded edition. Transaction Publishers.

Lee, A. (2011). Who becomes a terrorist?: Poverty, education, and the origins of political violence. World Politics, 63, pp 203-245 doi:10.1017/S0043887111000013.

Lyons-Padilla, S., Gelfand, M. J., Mirahmadi, H., Farooq, M., \& van Egmond, M. (2015). Belonging nowhere: Marginalization \& radicalization risk among Muslim immigrants. Behavioral Science \& Policy, 1(2), 1-12.

Manno, B. \& Graham, H. (2001). Research on Catholic school effectiveness. In Hunt, T. C., Joseph, E. A., \& Nuzzi, R. J. (Eds.), Handbook of Research on Catholic Education. Westport, CT: Greenwood Press.

Maranto, R. \& Raemdonck, D. C. V. (2015, January 8). Letting education and religion overlap. Why expanding vouchers to include parochial schools is a good idea. The Wall Street 
Journal. Retrieved from http://www.wsj.com/articles/robert-maranto-and-dirk-c-van$\underline{\text { raemdonck-letting-education-and-religion-overlap-1420761949 }}$

Merry, M. S., \& Driessen, G. (2016). On the right track? Islamic schools in the Netherlands after an era of turmoil. Race Ethnicity and Education, 19(4), 856-879.

Mills, J. N., \& Wolf, P. J. (2016). The effects of the Louisiana scholarship program on student achievement after two years. Available at SSRN 2738805.

McDonald, D. (2000). United States Catholic elementary and secondary schools 1999-2000: Annual statistical report on schools, enrollment and staffing. Washington, DC: National Catholic Educational Association.

Mohme, G. (2017). Somali Swedes' reasons for choosing a Muslim-profiled school— Recognition and educational ambitions as important influencing factors. Journal of School Choice, 1-19.

Mueller, J. E. (Ed.). (2013). Terrorism since 9/11: The American cases. Retrieved from http://politicalscience.osu.edu/faculty/jmueller/since.html

Muralidharan, K., \& Sundararaman. V. (2015). The aggregate effect of school choice evidence from a two-stage experiment in India. The Quarterly Journal of Economics, 130(3), 1011-1066.

National Center for Education Statistics. (2017a). Private School Survey 2013-14. Retrieved from: https://nces.ed.gov/surveys/pss/privateschoolsearch/.

National Center for Education Statistics. (2017b). Fast facts. Retrieved from: https://nces.ed.gov/fastfacts/display.asp?id=65.

New America (2017). Part II. Who are the terrorists? Retrieved from https://www.newamerica.org/in-depth/terrorism-in-america/who-are-terrorists/. 
Oakford, S. (2014). Muslim scholars make the theological case against the Islamic State. Retrieved from https://news.vice.com/article/muslim-scholars-make-the-theological-caseagainst-the-islamic-state

O'Neill, M. R. (2010). Muslim mothers: Pioneers of Islamic education in America (Doctoral dissertation, College Of Notre Dame Of Maryland).

Pape, R. (2005). Dying to win: The strategic logic of suicide terrorism. Random House.

Powell, A. G., Farrar, E., \& Cohen, D. K. (1985). The shopping mall high school. Winners and losers in the educational marketplace. Boston: Houghton Mifflin.

Roy, O. (2008). Islamic terrorist radicalisation in Europe. European Islam. Challenges for public policy and society, Brussels: Centre for European Policy Studies, 52-60.

Schbley, A. (2003). Defining religious terrorism: A causal and anthological profile. Studies in Conflict and Terrorism, 26(2), 105-134.

Shafiq, M. N., \& Myers, J. P. (2014). Educational vouchers and social cohesion: A statistical analysis of student civic attitudes in Sweden, 1999-2009. American Journal of Education, 121(1), 111-136.

Smith, J. (2000). Islam in America. New York: Colombia University Press.

Stern, J. (2000). Pakistan's Jihad culture. Foreign Affairs, 115-126.

Stern, J. (2016). Radicalization to extremism and mobilization to violence. What have we learned and what can we do about It?. The ANNALS of the American Academy of Political and Social Science, 668(1), 102-117.

Stotsky, S. (2011). The stealth curriculum. In Sarah N. Stern (eds.) Saudi Arabia and the global Islamic terrorist network. New York: Palgrave/Macmillan. 
Tooley, J. (2009). The beautiful tree: A personal journey into how the world's poorest people are educating themselves, Washington, D. C.: Cato Institute.

Trivitt, J., \& Wolf, P.J. (2011). School choice and the branding of Catholic schools. Education Finance and Policy, 6(2), 202-245.

Ummid news. (2015). 40\% of Muslim world's population unable to read or write: Study. Retrieved from http://www.ummid.com/news/2015/February/11.02.2015/literacy-in$\underline{\text { muslim-world.html }}$

Weaver, M. A. (2015, April 14). Her majesty's jihadists. The New York Times, p. SR12. Retrieved from https://www.nytimes.com/2015/04/19/magazine/her-majestysjihadists.html?_r=0

Wolf, P. J., \& Macedo, S. (Eds.). (2004). Educating citizens: International perspectives on civic values and school choice. Brookings Institution Press.

Wolf, P. J. (2007). Civics exam. Education Next, 7(3). Retrieved from http://educationnext.org/civics-exam/.

Wolf, P. J. (2008). School voucher programs: What the research says about parental school choice. BYU L. Rev., 415.

Wolf, P. J. (2016). In tribute: Jaap Dronkers, 1945-2016. Journal of School Choice, 10(2), 137139. Retrieved from http://www.tandfonline.com/doi/full/10.1080/15582159.2016.1176786.

Zine, J. (2006). Unveiled sentiments: Gendered Islamophobia and experiences of veiling among Muslim girls in a Canadian Islamic school. Equity \& Excellence in Education, 39(3), 239-252. 
Table 1 A: Successful jihadist terror attacks committed in U.S. by U.S. born and raised individuals since $9 / 11$.

\begin{tabular}{|c|c|c|c|c|c|}
\hline Category & Name & Description & Year & $\begin{array}{l}\text { School } \\
\text { Type } \\
\text { Attended }\end{array}$ & School Name \\
\hline Jihadist & $\begin{array}{l}\text { John Allen } \\
\text { Muhammad }\end{array}$ & $\begin{array}{l}\text { Killed by suspects prior to the } \\
\text { spree in Washington DC }\end{array}$ & 2002 & Public & $\begin{array}{l}\text { Scotlandville } \\
\text { Magnet High } \\
\text { School }\end{array}$ \\
\hline Jihadist & $\begin{array}{l}\text { Joel Henry } \\
\text { Hinrichs III }\end{array}$ & $\begin{array}{l}\text { University of Oklahoma } \\
\text { Bombing }\end{array}$ & 2005 & Public & $\begin{array}{l}\text { Roy J. } \\
\text { Wasson High } \\
\text { School }\end{array}$ \\
\hline Jihadist & $\begin{array}{l}\text { Naveed } \\
\text { Afzal Haq }\end{array}$ & $\begin{array}{l}\text { Seattle Jewish Federation } \\
\text { Shooting }\end{array}$ & 2006 & Public & $\begin{array}{l}\text { Richland } \\
\text { High School } \\
\text { (Washington) }\end{array}$ \\
\hline Jihadist & $\begin{array}{l}\text { Abdulhakim } \\
\text { Mujahid } \\
\text { Muhammad }\end{array}$ & Little Rock Shooting & 2009 & Public & $\begin{array}{l}\text { Memphis' } \\
\text { Craigmont } \\
\text { High School }\end{array}$ \\
\hline Jihadist & $\begin{array}{l}\text { Major Nidal } \\
\text { Hasan }\end{array}$ & Fort Hood Shooting & 2009 & Public & $\begin{array}{l}\text { William } \\
\text { Fleming High } \\
\text { School }\end{array}$ \\
\hline Jihadist & $\begin{array}{l}\text { Yusuf } \\
\text { Ibrahim }\end{array}$ & $\begin{array}{l}\text { Ibrahim shot and killed 25- } \\
\text { year-old Hanny Tawadros and } \\
27 \text {-year-old Amgad Konds } \\
\text { after he abducted them in } \\
\text { February } 2013 \text { and buried } \\
\text { them in a shallow grave in } \\
\text { Atlantic County. }\end{array}$ & 2013 & & \\
\hline Jihadist & $\begin{array}{l}\text { Ali } \\
\text { Muhammad } \\
\text { Brown }\end{array}$ & $\begin{array}{l}\text { Washington and New Jersey } \\
\text { Killing Spree }\end{array}$ & 2014 & & \\
\hline Jihadist & $\begin{array}{l}\text { Ismaaiyl } \\
\text { Brinsley }\end{array}$ & $\begin{array}{l}\text { shot two NYPD cops in } \\
\text { Brooklyn's Bed Stuy } \\
\text { neighborhood }\end{array}$ & 2014 & & \\
\hline Jihadist & $\begin{array}{l}\text { Zale } \\
\text { Thompson }\end{array}$ & Queens hatchet attack & 2014 & & \\
\hline Jihadist & $\begin{array}{l}\text { Syed } \\
\text { Rizwan } \\
\text { Farook }\end{array}$ & $\begin{array}{l}\text { San Bernardino shooting in } \\
\text { California }\end{array}$ & 2015 & Public & $\begin{array}{l}\text { La Sierra } \\
\text { High School }\end{array}$ \\
\hline Jihadist & $\begin{array}{l}\text { Omar Mir } \\
\text { Seddique } \\
\text { Mateen }\end{array}$ & Orlando nightclub shooting & 2016 & Public & $\begin{array}{l}\text { Martin } \\
\text { County High } \\
\text { School }\end{array}$ \\
\hline Jihadist & $\begin{array}{l}\text { Joshua } \\
\text { Cummings }\end{array}$ & $\begin{array}{l}\text { Colorado Security Guard } \\
\text { Shooting }\end{array}$ & 2017 & & \\
\hline
\end{tabular}


Note: Results are derived from basic internet searches. Cells for which data was not available through internet searches have been left blank.

Table 1 B. Successful right wing terror attacks committed in U.S. by U.S. born and raised individuals since $9 / 11$.

\begin{tabular}{|c|c|c|c|c|c|}
\hline Category & Name & Description & Year & $\begin{array}{l}\text { School Type } \\
\text { Attended }\end{array}$ & School Name \\
\hline $\begin{array}{l}\text { Right } \\
\text { Wing }\end{array}$ & Wade Lay & $\begin{array}{l}\text { Tulsa OK, Bank } \\
\text { Robbery }\end{array}$ & 2004 & & \\
\hline $\begin{array}{l}\text { Right } \\
\text { Wing }\end{array}$ & $\begin{array}{l}\text { Christopher } \\
\text { Lay }\end{array}$ & $\begin{array}{l}\text { Tulsa OK, Bank } \\
\text { Robbery }\end{array}$ & 2004 & & \\
\hline $\begin{array}{l}\text { Right } \\
\text { Wing }\end{array}$ & $\begin{array}{l}\text { Jim David } \\
\text { Adkisson }\end{array}$ & $\begin{array}{l}\text { Knoxville, TN } \\
\text { Church Shooting }\end{array}$ & 2008 & & \\
\hline $\begin{array}{l}\text { Right } \\
\text { Wing }\end{array}$ & Keith Luke & $\begin{array}{l}\text { Brockton, MA } \\
\text { Murders }\end{array}$ & 2009 & Public & $\begin{array}{l}\text { Brockton High } \\
\text { School }\end{array}$ \\
\hline $\begin{array}{l}\text { Right } \\
\text { Wing }\end{array}$ & Scott Roeder & $\begin{array}{l}\text { George Tiller } \\
\text { Assassination }\end{array}$ & 2009 & Public & $\begin{array}{l}\text { Topeka High } \\
\text { School }\end{array}$ \\
\hline $\begin{array}{l}\text { Right } \\
\text { Wing }\end{array}$ & $\begin{array}{l}\text { James Von } \\
\text { Brunn }\end{array}$ & $\begin{array}{l}\text { Holocaust Museum } \\
\text { Shooting }\end{array}$ & 2009 & Public & $\begin{array}{l}\text { JvB was educated } \\
\text { in public schools }\end{array}$ \\
\hline $\begin{array}{l}\text { Right } \\
\text { Wing }\end{array}$ & $\begin{array}{l}\text { Robert } \\
\text { Andrew } \\
\text { Poplawski }\end{array}$ & $\begin{array}{l}\text { Pittsburgh Police } \\
\text { Shootings }\end{array}$ & 2009 & Private & $\begin{array}{l}\text { North Catholic } \\
\text { High School }\end{array}$ \\
\hline $\begin{array}{l}\text { Right } \\
\text { Wing }\end{array}$ & $\begin{array}{l}\text { Albert Robert } \\
\text { Gaxiola }\end{array}$ & $\begin{array}{l}\text { Flores Murders, } \\
\text { Pima County, AZ }\end{array}$ & 2009 & & \\
\hline $\begin{array}{l}\text { Right } \\
\text { Wing }\end{array}$ & $\begin{array}{l}\text { Jason Eugene } \\
\text { Bush }\end{array}$ & $\begin{array}{l}\text { Flores Murders, } \\
\text { Pima County, AZ }\end{array}$ & 2009 & & \\
\hline $\begin{array}{l}\text { Right } \\
\text { Wing }\end{array}$ & Shawna Forde & $\begin{array}{l}\text { Flores Murders, } \\
\text { Pima County, AZ }\end{array}$ & 2009 & & \\
\hline $\begin{array}{l}\text { Right } \\
\text { Wing }\end{array}$ & $\begin{array}{l}\text { Andrew } \\
\text { Joseph Stack }\end{array}$ & $\begin{array}{l}\text { Austin, TX Plane } \\
\text { Attack }\end{array}$ & 2010 & Private & $\begin{array}{l}\text { Milton Hershey } \\
\text { School }\end{array}$ \\
\hline $\begin{array}{l}\text { Right } \\
\text { Wing }\end{array}$ & $\begin{array}{l}\text { Raymond } \\
\text { Franklin Peake }\end{array}$ & $\begin{array}{l}\text { Carlisle, PA } \\
\text { Murder }\end{array}$ & 2010 & & \\
\hline $\begin{array}{l}\text { Right } \\
\text { Wing }\end{array}$ & Isaac Aguigui & Fear militia & 2011 & $\begin{array}{l}\text { Home } \\
\text { Schooled }\end{array}$ & \\
\hline $\begin{array}{l}\text { Right } \\
\text { Wing }\end{array}$ & $\begin{array}{l}\text { Heather } \\
\text { Salmon }\end{array}$ & Fear militia & 2011 & & \\
\hline
\end{tabular}




\begin{tabular}{|c|c|c|c|c|c|}
\hline $\begin{array}{l}\text { Right } \\
\text { Wing }\end{array}$ & $\begin{array}{l}\text { Anthony } \\
\text { Peden }\end{array}$ & Fear militia & 2011 & & \\
\hline $\begin{array}{l}\text { Right } \\
\text { Wing }\end{array}$ & $\begin{array}{l}\text { Christopher } \\
\text { Salmon }\end{array}$ & Fear militia & 2011 & & \\
\hline $\begin{array}{l}\text { Right } \\
\text { Wing }\end{array}$ & $\begin{array}{l}\text { Michael } \\
\text { Burnett }\end{array}$ & Fear militia & 2011 & & \\
\hline $\begin{array}{l}\text { Right } \\
\text { Wing }\end{array}$ & $\begin{array}{l}\text { Wade Michael } \\
\text { Page }\end{array}$ & $\begin{array}{l}\text { Sikh Temple } \\
\text { Shooting }\end{array}$ & 2012 & Public & $\begin{array}{l}\text { Littleton High } \\
\text { School, Arapahoe } \\
\text { High School }\end{array}$ \\
\hline $\begin{array}{l}\text { Right } \\
\text { Wing }\end{array}$ & $\begin{array}{l}\text { Kyle David } \\
\text { Joekel }\end{array}$ & $\begin{array}{l}\text { St. John's Parish } \\
\text { Police Ambush }\end{array}$ & 2012 & Public & $\begin{array}{l}\text { Freeman High } \\
\text { School }\end{array}$ \\
\hline $\begin{array}{l}\text { Right } \\
\text { Wing }\end{array}$ & $\begin{array}{l}\text { Holly Ann } \\
\text { Grigsby }\end{array}$ & $\begin{array}{l}\text { Tri-State Killing } \\
\text { Spree }\end{array}$ & 2012 & Public & $\begin{array}{l}\text { Parkrose High } \\
\text { School }\end{array}$ \\
\hline $\begin{array}{l}\text { Right } \\
\text { Wing }\end{array}$ & $\begin{array}{l}\text { David Joey } \\
\text { Pederson }\end{array}$ & $\begin{array}{l}\text { Tri-State Killing } \\
\text { Spree }\end{array}$ & 2012 & Public & $\begin{array}{l}\text { North Salem High } \\
\text { School }\end{array}$ \\
\hline $\begin{array}{l}\text { Right } \\
\text { Wing }\end{array}$ & Eric Frein & $\begin{array}{l}\text { Blooming Grove } \\
\text { Police Shooting }\end{array}$ & 2012 & Public & $\begin{array}{l}\text { Pocono Mountain } \\
\text { High School }\end{array}$ \\
\hline $\begin{array}{l}\text { Right } \\
\text { Wing }\end{array}$ & Derrick Smith & $\begin{array}{l}\text { St. John's Parish } \\
\text { Police Ambush }\end{array}$ & 2012 & & \\
\hline $\begin{array}{l}\text { Right } \\
\text { Wing }\end{array}$ & Terry Smith & $\begin{array}{l}\text { St. John's Parish } \\
\text { Police Ambush }\end{array}$ & 2012 & & \\
\hline $\begin{array}{l}\text { Right } \\
\text { Wing }\end{array}$ & Chanel Skains & $\begin{array}{l}\text { St. John's Parish } \\
\text { Police Ambush }\end{array}$ & 2012 & & \\
\hline $\begin{array}{l}\text { Right } \\
\text { Wing }\end{array}$ & Britney Keith & $\begin{array}{l}\text { St. John's Parish } \\
\text { Police Ambush }\end{array}$ & 2012 & & \\
\hline $\begin{array}{l}\text { Right } \\
\text { Wing }\end{array}$ & $\begin{array}{l}\text { Brian Lyn } \\
\text { Smith }\end{array}$ & $\begin{array}{l}\text { St. John's Parish } \\
\text { Police Ambush }\end{array}$ & 2012 & & \\
\hline $\begin{array}{l}\text { Right } \\
\text { Wing }\end{array}$ & Jerad Miller & $\begin{array}{l}\text { Las Vegas Police } \\
\text { Ambush }\end{array}$ & 2014 & Public & $\begin{array}{l}\text { Kennewick High } \\
\text { School }\end{array}$ \\
\hline $\begin{array}{l}\text { Right } \\
\text { Wing }\end{array}$ & Amanda Miller & $\begin{array}{l}\text { Las Vegas Police } \\
\text { Ambush }\end{array}$ & 2014 & Public & $\begin{array}{l}\text { Jefferson High } \\
\text { School }\end{array}$ \\
\hline $\begin{array}{l}\text { Right } \\
\text { Wing }\end{array}$ & $\begin{array}{l}\text { Frazier Glenn } \\
\text { Cross }\end{array}$ & $\begin{array}{l}\text { Kansas Jewish } \\
\text { Center Shooting }\end{array}$ & 2014 & & \\
\hline $\begin{array}{l}\text { Right } \\
\text { Wing }\end{array}$ & Dylann Roof & $\begin{array}{l}\text { Charleston Church } \\
\text { Shooting }\end{array}$ & 2015 & Public & $\begin{array}{l}\text { White Knoll High } \\
\text { School }\end{array}$ \\
\hline $\begin{array}{l}\text { Right } \\
\text { Wing }\end{array}$ & Robert Dear & $\begin{array}{l}\text { Colorado Planned } \\
\text { Parenthood } \\
\text { Shooting }\end{array}$ & 2015 & & \\
\hline
\end{tabular}




\begin{tabular}{|l|l|l|l|l|l|}
\hline $\begin{array}{l}\text { Right } \\
\text { Wing }\end{array}$ & $\begin{array}{l}\text { James Harris } \\
\text { Jackson }\end{array}$ & $\begin{array}{l}\text { New York } \\
\text { Stabbing }\end{array}$ & 2017 & Private & $\begin{array}{l}\text { Friends School of } \\
\text { Baltimore }\end{array}$ \\
\hline
\end{tabular}

Note: Results are derived from basic internet searches. Cells for which data was not available through internet searches have been left blank. 